\title{
Fibrin Degradation Products in Sera of Normal Subjects
}

\author{
P. C. DAS,* M.B., B.S.; A. G. E. ALLAN, † F.I.M.L.T.; D. G. WOODFIELD, $\ddagger$ M.B., CH.B., M.R.C.P.ED. \\ J. D. CASH,§ M.B., CH.B., B.SC., PH.D., M.R.C.P.ED.
}

Brit. med. F., 1967, 4, 718-720

During the proteolysis of fibrinogen and fibrin by the fibrinolytic enzyme plasmin several large fragments are released which are incapable of undergoing further digestion (Nussenzweig and Seligmann, 1960 ; Alkjaersig et al., 1962). Some of these fragments, with a molecular weight of approximately 88,000 , contain an antigenic determinant which is identical to the parent fibrinogen (Nussenzweig et al., 1961). An accurate quantitative estimation of circulating fibrin/fibrinogen degradation products (F.D.P.) would be of considerable importance in investigations of physiological and pathological states of coagulation and fibrinulysis, for circulating F.D.P. represent a certain criterion that fibrinolysis is taking place. They play a significant part in the pathogenesis of certain bleeding disorders (Niewiarowski et al., 1959 ; Fletcher, 1966 ; Jerushalmy and Zucker, 1966 ; Kopéc et al., 1966); they may be of importance in the physiological control of the microcirculation (Buluk et al., 1966) and could provide valuable information in further studies on the hypothesis of a continuous dynamic equilibrium between fibrin deposition and fibrinolysis postulated to be an important aetiological factor in thrombosis and atherosclerosis (Astrup, 1956).

While prolongation of the thrombin time has been advocated as a useful screening procedure for estimating high levels of F.D.P. in pathological fibrinolysis (Sherry, 1965), the method is devoid of specificity, has poor sensitivity, and is therefore of limited value. The application of immunological techniques such as immunodiffusion and immunoelectrophoresis has greatly extended the specificity and sensitivity of F.D.P. assays. Further progress has been made with the use of a tanned red cell haemagglutination inhibition immunoassay (Murakami, 1965a ; Merskey et al., 1966) which has been claimed to be more sensitive and more easily adapted to accurate quantitative estimation of circulating F.D.P. than either immunodiffusion or immunoelectrophoresis. This investigation was designed to establish the normal range of serum F.D.P. values before the study of those pathological conditions believed to be associated with excessive focal or disseminated intravascular coagulation and to extend our studies of the Astrup hypothesis. This communication describes our experiences with the tanned red cell haemagglutination inhibition immunoassay in a group of apparently healthy subjects.

\section{Methods}

A total of 106 healthy volunteers (62 male and 44 female) aged 21-64 years (mean $40 \pm 15$ ) were studied. Cubital venous blood samples were obtained by clean venepuncture with the minimum venous occlusion, a plastic disposable syringe being used, after a period of 20 to 30 minutes' rest.

Five millilitres of blood was added to a non-siliconized glass test-tube containing $0.1 \mathrm{ml}$. of Trasylol $(5,000$ units $/ \mathrm{ml}$.) and placed in a water-bath at $37^{\circ} \mathrm{C}$. for four hours. The serum was removed after centrifugation at 2,000 r.p.m. for 10 minutes, and one-tenth of its volume of thrombin (100 units/ml.) was

\footnotetext{
- Honorary Registrar.

t Senior Technician.

Registrar.

Senios Registrar.

South-east Scotland Regional Blood Transfusion Research Laboratories, Royal Infirmary, Edinburgh 3.
}

added and incubated for 30 minutes at $37^{\circ} \mathrm{C}$. to remove any residual fibrinogen. F.D.P. assays were performed by the method of Merskey et al. (1966) on serum samples which had previously been absorbed for two hours at $4^{\circ} \mathrm{C}$. with one volume of saline-washed normal sheep red cells to two volumes of serum. Rabbit anti-human fibrinogen serum supplied by Hoechst Pharmaceuticals Ltd. was used in the immunoassay. Daily controls were run with standard solutions of human
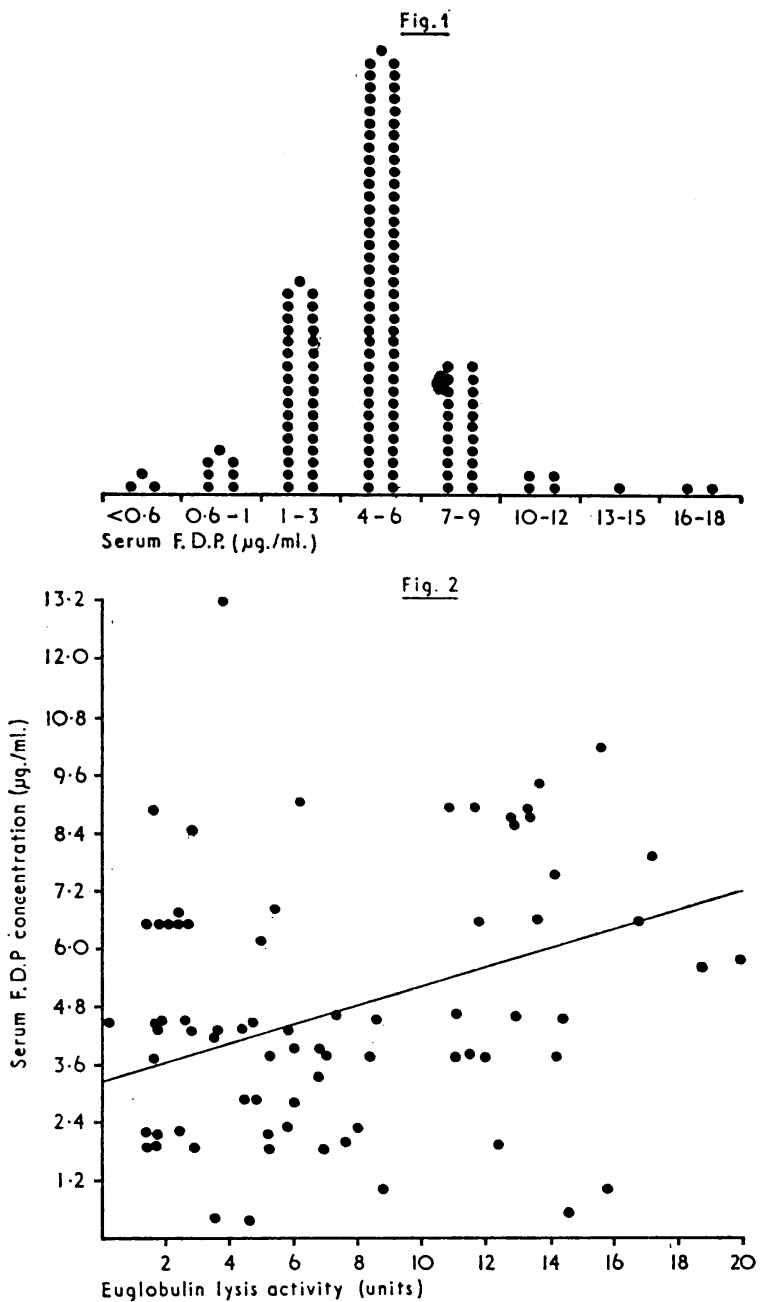

Fig. 1-Frequency distribution of serum F.D.P. of 147 samples from 106 normal subiects. Fig. 2.-Corrclation between serum F.D P. and plasma euglobulin lysis activity in 75 normal subiects. $r=0.226 ; 0.05<P<0.02 ; g=6.82+0.20 x$.

fibrinogen prepared by the Blombäck and Blombäck method and supplied by Kabi Pharmaceuticals Lid. The quantity of clottable protein in these solutions was checked perindically by the method of Ratnoff and Menzie (1951) as modified by Alkjaersig (1960). The immunoassay was sufficiently sensitive to demonstrate fibrinogen levels of $0.6 \mu \mathrm{g} . / \mathrm{ml}$.

A further $9 \mathrm{ml}$. of blood was added to $1 \mathrm{ml}$. of $3.8 \%$ sodium citrate, in a previously cooled siliconized glass centrifuge tube, 
and centrifuged at $4^{\circ}$ C. for 20 minutes at 3,400 r.p.m. Euglobulin lysis time assays were performed by the method described previously (Cash, 1966), but the clot lysis end-point was recorded objectively by means of an automatic clot lysis recorder (Cash and Leask, 1967). The euglobulin lysis activity was expressed in arbitrary units derived from the formula 1300/T of Janusko and Dubinska (1964), where $T$ was the euglobulin lysis time in minutes.

\section{Results}

Normal Resting Level of Serum F.D.P.-The mean serum F.D.P. level of 147 samples from 106 subjects was $4.9 \pm 2.8$ $\mu \mathrm{g} . / \mathrm{ml}$. The distribution of these values is shown in Fig. 1, and it can be seen that the immunoassay was able to detect F.D.P. in all but $2 \%$ of the serum samples. No significant sex difference was shown, nor was there a consistent change in serum F.D.P. throughout a menstrual cycle in the four women studied. Table 1 gives the individual variation in serum F.D.P. of 12 subjects from whom blood was withdrawn at weekly intervals, whereas Table II shows the variability of the assay system on aliquots of eight serum samples which were stored at $-40^{\circ} \mathrm{C}$. and assayed at weekly intervals.

Exercise and Adrenaline Studies.-Table III shows the serum F.D.P. levels in 26 subjects before and after an eight-minute exercise procedure on a treadmill moving at 3.4 m.p.h. (5.5 k.p.h.) at 5 degrees elevation, and in five subjects before

TABLE I.-Serum F.D.P. Levels ( $\left(\mu g_{.} / \mathrm{ml}\right.$ ) $)$ of Blood Samples Withdrawn at Weekly Intervals from 12 Normal Resting Subjects

\begin{tabular}{c|c|c|c|c|c|c|c|c|c|c|c}
\hline 1 & 2 & 3 & 4 & 5 & 6 & 7 & 8 & 9 & 10 & 11 & 12 \\
\hline 6.1 & 2.0 & $8 \cdot 2$ & 4.5 & 3.7 & 1.9 & 6.5 & 2.2 & 6.5 & 4.5 & 8.8 & 2.3 \\
2.9 & 2.2 & 7.8 & 4.5 & 1.9 & $<0.6$ & 8.6 & 2.2 & 6.5 & 4.5 & 8.9 & 2.3 \\
2.9 & 4.6 & 10.1 & 3.7 & 4.6 & 4.6 & 6.5 & 4.3 & 6.5 & 8.9 & 8.9 & 6.8 \\
- & - & - & 3.7 & - & 4.5 & - & - & - & 11.7 & - & - \\
\hline
\end{tabular}

TABLB II.-F.D.P. Level (ug./ml.) of Eight Serum Samples, Aliquots of Which Were Kept at $-40^{\circ} \mathrm{C}$. and Assayed at Weekly Intervals

\begin{tabular}{c|c|c|c|c|c|c|c}
\hline \multicolumn{1}{c}{ Sample No. } \\
\hline 1 & 2 & 3 & 4 & 5 & 6 & 7 & 8 \\
\hline 3.0 & 9.0 & 4.8 & 6.6 & 4.8 & 7.8 & 7.8 & 15.6 \\
3.0 & 9.0 & 4.8 & 9.0 & 4.8 & 8.4 & 7.8 & 19.0 \\
3.0 & 9.0 & 4.8 & 6.6 & 5.4 & 7.8 & 7.8 & 15.6 \\
\hline
\end{tabular}

TABLE III.-Serum F.D.P. Levels Before and After a Moderate Exercise and Intravenous Adrenaline Procedure

\begin{tabular}{|c|c|c|c|c|c|}
\hline \multicolumn{3}{|c|}{ Exercise } & \multicolumn{3}{|c|}{ Adrenaline } \\
\hline \multirow{2}{*}{$\begin{array}{l}\text { Subject } \\
\text { No. }\end{array}$} & \multicolumn{2}{|c|}{$\underset{(\mu \mathrm{g} . / \mathrm{ml} .)}{\text { Serum F.P. }}$} & \multirow{2}{*}{$\begin{array}{l}\text { Subject } \\
\text { No. }\end{array}$} & \multicolumn{2}{|c|}{$\begin{array}{c}\text { Serum F.D.P. } \\
(\mu \mathrm{g} . / \mathrm{ml} .)\end{array}$} \\
\hline & Before & After & & Before & After \\
\hline $\begin{array}{c}1 \\
2 \\
3 \\
4 \\
5 \\
6 \\
7 \\
7 \\
9 \\
9 \\
10 \\
11 \\
12 \\
13 \\
14 \\
15 \\
16 \\
17 \\
18 \\
19 \\
20 \\
21 \\
22 \\
23 \\
24 \\
25 \\
26\end{array}$ & $\begin{array}{r}3.2 \\
1.8 \\
1.8 \\
1.0 \\
3.7 \\
3.7 \\
1.9 \\
3.7 \\
1.9 \\
1.5 \\
3.4 \\
3.6 \\
2.4 \\
5.2 \\
3.0 \\
2.2 \\
3.0 \\
4.3 \\
3.2 \\
4.5 \\
4.1 \\
5.7 \\
6.7 \\
8.8 \\
10.2 \\
6.8\end{array}$ & $\begin{array}{r}12.5 \\
6.2 \\
12.4 \\
6.2 \\
14.0 \\
18.7 \\
6.2 \\
18.7 \\
6.2 \\
14.4 \\
16.8 \\
8.0 \\
9.8 \\
11.4 \\
10.5 \\
8.6 \\
8.6 \\
12.2 \\
8.2 \\
13.6 \\
11.3 \\
12.2 \\
10.4 \\
13.4 \\
13.6 \\
10.2\end{array}$ & $\begin{array}{l}1 \\
2 \\
3 \\
4 \\
5\end{array}$ & $\begin{array}{r}6.2 \\
10.9 \\
3.1 \\
1.6 \\
4.9\end{array}$ & $\begin{array}{l}18.7 \\
24.9 \\
12.5 \\
6.2 \\
14.0\end{array}$ \\
\hline Mean & $3 \cdot 3$ & 6.7 & Mean & 3.3 & $9 \cdot 1$ \\
\hline
\end{tabular}

and two minutes after a two-minute intravenous infusion of $10 \mu \mathrm{g}$. of adrenaline per minute (Parke-Davis and Co.). Statistical analysis of these results by Student's $t$ test showed the resultant increases of serum F.D.P. to be significant (exercise, $t=5.922, \mathrm{P}<0.001$; adrenaline, $t=3.03,0.005<\mathrm{P}<0.01$ ).

Correlation Between Serum F.D.P. and Euglobulin Lysis Activity.-A plot of the resting serum F.D.P. values and plasma euglobulin lysis activity in 75 samples (Fig. 2) shows a significant correlation between these two criteria $(r=0.226$; $0.02<\mathrm{P}<0.05 ; \mathrm{y}=6.82+0.20 \mathrm{x})$.

\section{Discussion}

There are few studies on the detection of F.D.P. in the serum of normal subjects: Ferreira and Murat (1963) and Ferri and Ferreira (1963), using a "fibrin degradation flocculation test" and immunoelectrophoresis, found no evidence of circulating F.D.P. in normal subjects ; Niléhn and Nilsson (1964), using comparative immunoelectrophoresis in agar gel, demonstrated F.D.P. in the serum in 5 of their 28 normal subjects; and Murakami (1965b), employing the tanned red cell haemagglutination inhibition immunoassay, observed lysis products without exception in 69 cases, including normal controls, whereas Merskey et al. (1966), using the same basic method, demonstrated the presence of F.D.P. in only 3 out of 33 controls.

The present investigation indicates that the tanned red cell haemagglutination inhibition immunoassay can show a serum F.D.P. content in about $95 \%$ of normal serum samples. This. high incidence of detection in normal sera does not accord with the findings of Merskey et al. (1966) but is similar to the observations of Murakami (1965b). At the present time it is not possible to explain these different results, but the greater sensitivity of our immunoassay and small differences in technique, reagents, and sheep red cells may be relevant factors. It is also possible that there was a difference in the age and sex ratio of the normal populations studied in the three different centres.

In view of the pathophysiological significance of these findings it is important to be certain that the assay system is in fact detecting products of degradation of in-vivo fibrin by the fibrinolytic enzyme system. It is possible that the fibrinopeptides (Blombäck et al., 1966) released during the clotting of the plasma fibrinogen were reacting positively in the immunoassay. However, we have shown that the supernatant, obtained after the incubation at $37^{\circ} \mathrm{C}$. for 30 minutes of purified fibrinogen with thrombin in the presence of Trasylol, does not produce haemagglutination inhibition. It is also possible that residual traces of fibrinogen remained in the sera despite the addition of thrombin. We have no evidence to substantiate this view and have found no correlation between the plasma fibrinogen and level of serum F.D.P. in 20 subjects.

Previous studies have indicated that exercise and adrenaline will bring about an increase in activity of both the coagulation and fibrinolytic enzyme systems (Biggs et al., 1947 ; Forwell and Ingram, 1957 ; Genton et al., 1961 ; Iatridis and Ferguson, 1963 ; Burt et al., 1964). The demonstration of a highly significant increase in circulating F.D.P. after these fibrinolytic stimulants would suggest that previous assumptions related to an increase in coagulation and fibrinolysis are valid and that the haemagglutination inhibition immunoassay is detecting real levels of F.D.P. Further collateral evidence in favour of this latter point was obtained by the observation of high levels of F.D.P. in a patient with severe haemorrhagic diathesis caused by a primary fibrinolysis associated with a hypernephroma. In this patient the F.D.P. level fell precipitously and bleeding stopped after the administration of aminocaproic acid. Subsequent efforts to withdraw the aminocaproic acid resulted in a rapid rise of serum F.D.P., associated with a return of bleeding, which was again controlled by resumption of the administration of aminocaproic acid. 
Though we showed a positive correlation between the resting levels of circulating F.D.P. and the plasminogen activator in normal subjects the relation was not highly significant. This indicates that the concentration of circulating F.D.P. is probably the end-result of a complex dynamic system which will include fibrin deposition and active fibrinolysis associated with fibrinolytic inhibition.

It cannot be assumed that the results of our study necessarily represent definite proof of continuous in-vivo intravascular coagulation and fibrinolysis as envisaged by Astrup, though the exercise and adrenaline studies are very suggestive. More information is required on the rate of excretion of circulating F.D.P. in physiological circumstances, for if the present concept of a half-life of approximately nine hours is substantiated (Sherry, 1965), then the resting values obtained in this study could merely represent the end-product of transient episodes of exercise or anxiety which occurred several hours before the blood was withdrawn. Furthermore, we have no proof that these F.D.P. are derived from intravascular deposits of fibrin, for it is possible that they may represent a by-product of minute damage and repair within the tissues. Further work on these problems is in progress.

\section{Summary}

From 106 apparently healthy subjects 147 serum samples were assayed for their fibrin degradation product (F.D.P.) content by the tanned red cell haemagglutination inhibition immunoassay technique. In $98 \%$ of these samples it was possible to detect a measurable quantity of F.D.P., the mean value being $4.9 \pm 2.8 \mu \mathrm{g} . / \mathrm{ml}$. There was no significant sex difference or a consistent change during the menstrual cycle. Further studies with the use of exercise and intravenous adrenaline were carried out in order to evaluate the significance of these findings in relation to the concept of an in-vivo dynamic equilibrium between coagulation and fibrinolysis.

We wish to thank Dr. R. A. Cumming, Director of the SouthEast Scotland Regional Blood Transfusion Centre, who has been responsible for the provision of our excellent laboratory facilities and has given us much encouragement and helpful advice, and Dr.
A. E. Robertson, who kindly assisted in obtaining the co-operation of many of our subjects. Finally we wish to express our sincere appreciation to Dr. Clarence Mlerskey, of the Albert Einstein College of Medicine, New York, U.S.A., whose helpful correspondence maintained our interest and played a significant part in the successful development of this assay. This research programme was supported by a grant from the Scottish Hospital Endowments Research Trust. One of us (P. C. D.) was in receipt of a postgraduate scholarship from the Government of East Pakistan.

Requests for reprints should be addressed to Dr. J. D. Cash, South-East Scotland Regional Blood Transfusion Research Laboratories, Royal Infirmary, Edinburgh 3.

\section{REFERENCES}

Alkjaersig, N. (1960). In N.I.H. Conference on Thrombolytic Agents, p. 316 , edited by H. R. Roherts and J. D. Geraty. Chapel Hill. - Fletcher, A. P., and Sherry, S. (1962). 7. clin. Invest., 41, 917

Astrup, I. (1956). Lancet, 2, 565 .

Bugys, R., Macfarlane, R. G., and Pilling, J. (1947). Ibid., 1, 402.

Blombäck, B., Blumback, M., Edman, P., and Hessel, B. (1966). Biochim. biophys. Acia (Amsi.), 115,371 .

Buluk, K., Malofieıw, M., and Ćzokalo, M. (1966). Bull. Acad. Pol. Sci., Cl. 2, 14, 193.

Burt, J. J., Blyth, C. S., and Rierson, H. A. (1964). F. Sport Med. (Iorino), 4, 213

Cash, J. D. (1960). Brit. med. 9., 2, 502.

and Leask, E. (1967). F. clin. Path., 20, 209.

Ferrerra, H. C., and Murat, L. G. (1963). Brit. F. Haemat., 9, 299.

Ferri, R. G., and Ferreira, H C. (1963). Vox Sang. (Basel), 8, 356.

Flewher, A. P. (1966). Fed Proc., 25, 84.

Forwell, G. D., and Ingram, G. I. C. (1957). F. Physiol. (Lond.), 135,

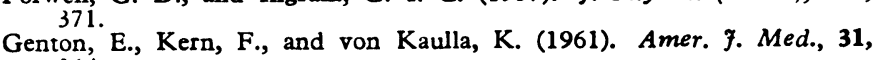
564.

Iarridis, S. G., and Ferguson, J. H. (1963). 7. appl. Physiol., 18, 337.

Janusko, T., and Dubinska, L. (1964). Konferencja Pol. Tow. Haematol., Krynica.

Jerushalmy, Z., and Zucker, M. B. (1966). Thrombos. Diathes. haemorrh. (Stultg.), 15, 413. (Stultg.), 15, 413.
Kopec, M., Budzyński, A., Stachurska, J., Wegrzynowicz, Z., and
Kuwaaski, E (1966). Ibid., 15, 476.

Merskey, C.. Kleiner, G. J., and Johnson, A. J. (1966). Blood, 28, 1.

Murakami, M. (1905a). Fap. 7. clin. Puth., 13, 542.

Murakams (1965). Acta haemal. jap., 28, 341 .

Niewiarow,ki, S., Latallo, Z., and Stachurska, J. (1959). Rev. Hémat., 14,118 .

Nilehn, J.-E., and Nilsson, I. M. (1964). Scand. F. Huemat., 1, 313.

Nussenzweig, V., and Seligmann, M. (1960). Rev. Hérnat., 15, 451. 377. Pelmont, J., and Grabar, P. (1961). Ann. Inst. Pasteur, 100, Ratnuff, O. D., and Menzie, C. (1951). F. Lab. clin. Med., 37, 316. Sherry, S. (1965). Series Haematologica (Copenhagen) 7, 70.

\section{Malignant Tumour of Brown Fat in Patient with Turner's Syndrome}

Brit. med. F., 1967, 4, 720-721

\section{CASE Report}

A 24-year-old typist was first seen in January 1966, when she complained of a slowly enlarging painless swelling in the right scapular region that had been present for one year. She had no other complaints, but on systematic questioning it was noted that she had primary amenorrhoea.

On examination there was a non-tender subcutaneous swelling measuring 5 by $5 \mathrm{~cm}$. below the right scapula. The tumour was not attached to skin but was attached to deep structures. There were no signs of inflammation, but there were some dilated veins over the tumour. The patient had a short stature with a total height of 54 in. $(137 \mathrm{~cm}$.) and an arm span of 60 in. $(142 \mathrm{~cm}$.). She had unusual facies with a small mandible, pmminent inner epicanthal folds, and large low-set ears. There was no webbung of the neck or cubitus valgus, but she had a low hair-line with syndactyly of the fingers and toes. The chest had a shield-like configuration. Breast development was present but slight. Pubic and dxillary hair were scanty. Blood pressure was $135 / 90 \mathrm{~mm}$. $\mathrm{Hg}$. Hypoplastic genitalia were noted on pelvic examination, and the ovaries could not be palpated.

Investigations. $-X$-ray examination showed a normal sella turcica and smali facial bones; the radial and ulnar epiphyses had not united, but fusion had occurred at all the epıphyses of the elbow. 17-Ketosteroids 4.3 and $5.5 \mathrm{mg} . / 24$ hours. 17-Hydroxycorticosteroids 12.4 and $4.4 \mathrm{mg} . / 24$ hours. After four days' A.C.T.H. stumulation 17-KS was 27.8 and $17-\mathrm{OHCS}$ was $26 \mathrm{mg} . / 24$ hours. Gunadotrophins 1.8-3.6 $\mathrm{\mu g} . / 24$ hours. Buccal smears showed a chromatin-negative pattern.

Five hundred neutrophils were examined and only one type $A$ and three type B appendages were seen (normal for female is six or more). There was a predominance of type $C$ nuclear appendages that are seen more often in the male. Blood culture gave a good growth of cells for chromosome studies. The model number was 45. Karyotypes from several cells showed the chromosome pattern of Turner's syndrome $45 / \mathrm{XO}$. However, a few cells with 46 chromusomes shuwed the normal number of chromosomes (16) in group C. The probable diagnosis seemed to be a mosaic with some cells containing $45 / \mathrm{XO}$ chromosomes and others $46 / \mathrm{XX}$. 